\title{
Antioxidant Polyphenol Glycosides from the Plant Draba nemorosa
}

\author{
Md. Aziz Abdur Rahman and Surk-Sik Moon

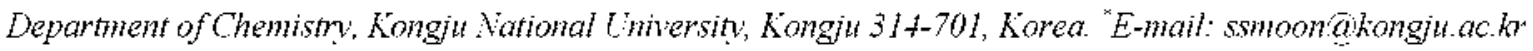 \\ Received February 23. 2007

\begin{abstract}
Bioassay-directed fractionation of Draba nemorosa led to the isolation of two new phenolic glycosides. 1-0(sinapoyl)-glucitol (2) and 1,3-disinapoylgentiobiose (5) along with five known phenolic glycosides (1. 3, 4. 6 . and 7). Their structures were characterized based on spectroscopic methods (2D NMR. HRTOFMS. IR, and UV). The isolated compounds showed antioxidant activities $\left(\mathrm{IC}_{5 i}\right)$ in the range of $14-98 \mathrm{mM}$ which were estimated by DPPH radical-scavenging assay.
\end{abstract}

Key Words : Draba nemorosa. Sinapoỵlglucitol. Disinapoylgentiobiose. Antioxidants

\section{Introduction}

In recent years, oxygen-derived free radicals have been reported to be closely involved in many biological symptoms such as inflammation, cancer, atherosclerosis. and coronary heart disease. ${ }^{1, \hat{}}$ Almost all organisms are protected from free radical attack by defense mechanisms. One such mechanism is a preventive antioxidant system that reduces the rate of radical formation, and another is a system to produce chain-breaking antioxidants that scavenge and stabilize free radicals. The free radical production rate may exceed the capacity of the antioxidant defense mechanisms which result in substantial tissues injury. ${ }^{3}$ Recent studies with regard to these aspects have suggested that the antioxidant activities of various agents such as antiallergic. nonsteroidal, and anti-inflammatory drigs. and traditional medicinal plants may provide clinically beneficial actions, ${ }^{+, 5}$ Thus. studies have been focused on the potential of plant products to find antioxidants against various diseases induced by free radicals. ${ }^{6}$ Additionally. it has been determined that the antioxidant effect of plant products is mainly due to radical-scavenging activity of phenolic compounds such as flaxonoids, poly phenols, tannins, and phenolic terpenes. ${ }^{7,8}$

In order to search compounds with antioxidant activity from the plants, the crude methanolic extracts from over two hundred Korean medicinal plants were prepared and tested using 2,2-dipheny l-1-picrylhydrazyl (DPPH) assay method. Of those plant extracts tested. an annual herb, Draba nemorosa (gotdazi. Korean common name). showed significant antioxidant activity ( $\mathrm{IC}_{50} 250 \mu \mathrm{g} / \mathrm{mL}$ ). This herb has been known to exhibit expectorant, stomachic, diuretic. antiscorbutic. anticarcinogenic, antiviral. and antihypertensive properties. ${ }^{9.11}$ However. the potential health benefits of the extracts of Draba nemorosa have not been studied in detail to date and phytochemical investigations have little been reported. ${ }^{1 \hat{1}, 13}$ Therefore. this plant might be a good candidate for further development as a nutraceutical or for its antioxidant remedies. These observations influenced us to characterize antioxidant ingredients of the plant as a part of our ongoing phy tochemical and biological investigations on Korean medicinal plants.
This paper describes the isolation and structure elucidation of two new compounds, 1-O-(sinapoyl)-glucitol (2) and 1.3disinapoylgentiobiose (5) together with five known compounds, sinapic acid (1), $\beta$-D-fructofuranosyl- $\alpha-\mathrm{D}-(6-\mathrm{O}-$ sinapoyl)-glucopyranoside (3). 1,2-disinapoyl- $\beta$-D-glucopyranoside (4). 1,2-disinapoylgentiobiose (6). and 1.2,2'trisinapoylgentiobiose (7). Antioxidant activities of the isolates evaluated by DPPH activity assay are also reported.

\section{Experimental Section}

The melting point was measured on a Fisher melting point apparatus and is uncorrected. High resolution TOF mass spectra were measured on a Waters LCT Premier mass spectrometer coupled with a Waters AQUITY HPLC system and data acquisition was achieved using MassLynx version 4.0 software. Optical rotations were measured on a Perkin Elmer s 341-LC polarimeter. UV and IR spectra were measured on a Shimadzu UV-240l PCR spectrometer and a Perkin-Elmer BXFT-IR spectrometer. respectively. NMR spectra were recorded on a Varian Mercury 400 spectrometer with standard pulse sequences operating at 400 and $100 \mathrm{MHz}$ in ${ }^{1} \mathrm{H}$ and ${ }^{13} \mathrm{C}$ NMR. respectively. ${ }^{1} \mathrm{H}$ and ${ }^{13} \mathrm{C}$ spectra were referenced relative to either methanol- $c_{4}(\mathrm{~d}=$ 3.30 and $49.15 \mathrm{ppm}$ for ${ }^{1} \mathrm{H}$ and ${ }^{13} \mathrm{C}$ NMR. respectively) or DMSO- $d_{6}\left(\delta=2.50\right.$ and 39.51 for ${ }^{1} \mathrm{H}$ and ${ }^{13} \mathrm{C}$ NMR, respectively). 2D NMR spectra (COSY, TOCSY, HSQC, HMBC) were recorded using the manufacturer's software VNMR 6.IC. Flash column chromatography was carried out on $\mathrm{C}_{1 \mathrm{~S}}(40-63 \mu \mathrm{m}$. 90 id $\times 70 \mathrm{~mm}$, Merck). Medium-pressure liquid chromatography (MPLC) was carried out on a FMI lab pump system using silica gel $60(25-40 \mu \mathrm{m}$. Daisogel. 30 id $\times 300 \mathrm{~mm}$, eluent: $85: 14.5: 0.5$ to $80: 18: 2$ $\mathrm{CH}_{2} \mathrm{Cl}_{2}-\mathrm{MeOH}-\mathrm{H}_{2} \mathrm{O}$, flow rate: $8 \mathrm{~mL} / \mathrm{min}$ ). Thin-layer chromatograply (TLC) was performed on precoated silica gel plates (Kieselgel $60 \mathrm{~F}_{25 .} .20 \times 20 \mathrm{~cm}, 0.25 \mathrm{~mm}$ thick, Merck). Spots were detected under UV light at 254 and 365 $\mathrm{nm}$ or by charring (dipping in methanol solution of $p$ anisaldehyde-sulfuric acid followed by heating). Reversed phase HPLC was performed on a Waters 600 model system with a photodiode array UV detector 996 using a $C_{1 \$}$ reverse 
phased silica gel column (Senshu pak. Pegasil ODS, 20 id $x$ $250 \mathrm{~nm}$ ) with a gradient elution of 30 to $51 \%$ aqueous $\mathrm{MeOH}$ over 10 min and 51 to $65 \%$ aqueous $\mathrm{MeOH}$ over 80 min with a flow rate of $7 \mathrm{~mL} / \mathrm{min}$.

Plant Material. The seeds of Draba nemorosa were purchased from the local market at Geumsan. Daejeon. Korea in August 2005 and identified by Dr. Eunkyu Lim at the Busong Clinic of Medicinal Herbs (Iksan. Korea). A voucher specimen is deposited at the Natural Product Chemistry Lab, Department of Chemistry, Kongju National University, Korea (identification number: SM1372).

Extraction and Isolation. The seeds $(6 \mathrm{~kg})$ were pulverized and soaked with a series of extraction solvents: $80 \%$ aqueous $\mathrm{MeOH}(8 \mathrm{~L})$ at room temperature for one week. $\mathrm{MeOH}(8 \mathrm{~L})$ for one week. and $\mathrm{CH}_{2} \mathrm{Cl}_{2}(7 \mathrm{~L})$ for 5 days. The extracts were pooled and evaporated under reduced pressure to yield brownish oily syrup ( $402 \mathrm{~g}$ ). The residue was suspended in $30 \%$ aqueous $\mathrm{MeOH}(1.4 \mathrm{~L})$ and was extracted with hexane $(900 \mathrm{~mL} \times 9)$. Aqueous methanolic layer was concentrated to give brownish residue $(190$ g) that was partitioned between $\mathrm{H}_{-} \mathrm{O}(1.2 \mathrm{~L})$ and butanol $(800 \mathrm{~mL} \times 4)$. Butanol fraction $(50 \mathrm{~g})$ was chromatographed on a $\mathrm{C}_{1}$ flash colunn eluting with $100 \% \mathrm{H}_{2} \mathrm{O}$ to $100 \%$ $\mathrm{MeOH}$ to give twelve fractions.

Fraction $4(3.2 \mathrm{~g})$ was triturated with EtOAc to give compound $1(150 \mathrm{mg}$ ) as a white solid and the filtrate ( $3 \mathrm{~g})$ was further fractionated by silica gel MPLC to give ten subfractions. Subfractions. 6 and 7. were subjected to silica MPLC and $C_{18}$ HPLC to afford $2(9 \mathrm{mg})$ as pale yellowish oil and $3(55 \mathrm{mg})$ as yellowish powder.

Fraction $6(4.5 \mathrm{~g})$ was further chromatographed using silica MPLC to give thirteen subfractions. Subfractions. 5, 6. 7, and 9. were further purified using $\mathrm{C}_{18} \mathrm{HPLC}$ to afford 4 (462 $\mathrm{mg}$ ) as pale yellow amorphous solid. $7(48 \mathrm{mg}$ ) as brownish oil, $5(+6 \mathrm{mg})$ as pale yellowish oil, and $6(900$ $\mathrm{mg}$ ) as yellowish oil. respectively.

1-O-(Sinapoyl)-glucitol (2): pale yellowish oil; $[\alpha]_{\mathrm{D}}^{3 \mathrm{i}}$ +5.13 (c $\left.0.13 . \mathrm{CH}_{3} \mathrm{OH}\right) ; \mathrm{UV}\left(\mathrm{CH}_{3} \mathrm{OH}\right): \lambda_{\max }(\log \varepsilon) 326$ (4.95). 238 (4.90). $203(4.97) \mathrm{nm}: \mathrm{IR}\left(\mathrm{NaCl}\right.$ plate): $v_{\text {max }}$ 3417. $2948,2849,1704,1633,1603.1516 .1462 .1427$. 1286. 1224. 1115. $1018 \mathrm{~cm}^{-1}$ : ${ }^{1} \mathrm{H} \mathrm{NMR}\left(\mathrm{CD}_{3} \mathrm{OD} .400 \mathrm{MHz}\right)$ : $\delta 7.66\left(\right.$ lH. d. $\left.J=16.0 \mathrm{~Hz} . \mathrm{H}-3^{\prime}\right), 6.91(2 \mathrm{H}$, s. H-5', 9') 6.43 $\left(1 \mathrm{H}, \mathrm{d} . J=16.0 \mathrm{~Hz} . \mathrm{H}-2^{\prime}\right), 4.46\left(1 \mathrm{H}, \mathrm{dd} . J=11.6 .6 .4 \mathrm{~Hz}, \mathrm{H}_{\mathrm{a}^{-}}\right.$ 1). $4.26\left(1 \mathrm{H} . \mathrm{dd}, J=11.6,2.8 \mathrm{~Hz}, \mathrm{H}_{\mathrm{b}}-1\right) .3 .97(1 \mathrm{H}, \mathrm{ddd}, J=$ 8.4. 6.4. $2.8 \mathrm{~Hz} . \mathrm{H}-2) .3 .91$ ( $1 \mathrm{H}, \mathrm{dd}, J=4.8 .2 .4 \mathrm{~Hz} . \mathrm{H}-4)$. $3.89\left(6 \mathrm{H} . \mathrm{s} . \mathrm{OCH} H_{3}\right) .3 .80(\mathrm{lH}$. ddd. $J=6.0,4.8 .4 .0 \mathrm{~Hz}$. H5), $3.70\left(1 \mathrm{H}, \mathrm{dd}, J=11.2 .4 .0 \mathrm{~Hz}, \mathrm{H}_{\mathrm{a}}-6\right), 3.68(1 \mathrm{H}, \mathrm{dd} . J=$ 8.4. $2.4 \mathrm{~Hz}, \mathrm{H}-3) .3 .61$ (lH. dd. $\left.J=11.2,6.0 \mathrm{~Hz} . \mathrm{H}_{\mathrm{b}}-6\right) \mathrm{ppm}$ : ${ }^{13} \mathrm{C}$ NMR (CD $\left.{ }_{j} \mathrm{OD} .100 \mathrm{MHz}\right): \delta 169.2\left(\mathrm{C}, \mathrm{C}-\mathrm{I}^{\prime}\right), 149.3(\mathrm{C}$. C.6'. 8') $147.0\left(\mathrm{CH}^{\prime}, \mathrm{C}-3^{\prime}\right), 139.5$ (C. C. $\left.-7^{\prime}\right), 126.6$ (C. C.4'). 115.9 (CH. C-2'). 106.9 (CH. C-5' 9'). 75.2 (CH. C-5). 73.4 (CH. C-3). $70.8(\mathrm{CH} . \mathrm{C}-2) .70 .7(\mathrm{CH} . \mathrm{C}-4) .67 .6\left(\mathrm{CH}_{2} \mathrm{C}-1\right)$. $64.3\left(\mathrm{CH}_{2} \mathrm{C}-6\right) .56 .9\left(\mathrm{CH}_{3}\right)$ ppm; HRTOFMS: $m z 389.1+48$ $[\mathrm{M}+\mathrm{H}]^{+}$(calcd. for $\mathrm{C}_{17} \mathrm{H}_{2+} \mathrm{O}_{10}+\mathrm{H}$. 389.1447); TLC (80:18: 2 $\left.\mathrm{CH}_{2} \mathrm{Cl}_{2}-\mathrm{MeOH}-\mathrm{H}_{3} \mathrm{O}\right): R_{f} 0.24$

6-0- $\beta$-D-Glucopyranosyl- $\beta$-D-(1-0-sinapoyl,3-O-sinapoyl)glucopyranose (5): pale yellowish oil: $[\alpha]_{\mathrm{D}}^{31)}:+1.41(c) 0.92$.
$\left.\mathrm{CH}_{3} \mathrm{OH}\right): \mathrm{UV}\left(\mathrm{CH}_{3} \mathrm{OH}\right): \lambda_{\text {max }}(\log \varepsilon) 328$ (4.51). $240(4.44)$, 202 (4.52) nm: IR (NaCl plate): $v_{\max } 3363.2940,1704$. 1633. 1604. 1515. 1456. 1427. 1339. 1285. 1226. 1156, $1115,910.828 .766 \mathrm{~cm}^{-1}:{ }^{1} \mathrm{H}$ NMR $\left(\mathrm{CD}_{3} \mathrm{OD}\right.$ and DMSO- $d k_{i}$, $2: 1$ ratio. $400 \mathrm{MHz}$ ): $\delta 7.71$ (1H. d. $J=16.0 \mathrm{~Hz}, \mathrm{H}-3^{\prime \prime \prime}$ ). 7.66 (1H. d. $\left.J=16.0 \mathrm{~Hz}, \mathrm{H}-3^{\prime \prime}\right) .6 .92\left(2 \mathrm{H}\right.$, s. H-5"'. $\left.9^{\prime \prime}\right) .6 .91(2 \mathrm{H}$, s. H-5". 9"), 6.54 (lH. d, $\left.J=16.0 \mathrm{~Hz}, \mathrm{H}-2^{\prime \prime \prime}\right), 6.44$ (lH. d. $J=$ $16.0 \mathrm{~Hz} . \mathrm{H}-2$ "). 5.75 (1H, d, $J=8.8 \mathrm{~Hz}, \mathrm{H}-\mathrm{l}), 5.22$ (l $\mathrm{H} . \mathrm{dd}, J$ $=9.2,8.8 \mathrm{~Hz} . \mathrm{H}-3), 4.36(\mathrm{lH}, \mathrm{d} . J=8.0 \mathrm{~Hz}, \mathrm{H}-\mathrm{l}), 4.2 \mathrm{l}(\mathrm{lH}$, brd. $\left.J=10.4 \mathrm{~Hz} . \mathrm{H}_{\mathrm{a}}-6\right), 3.88$ (12H. s. OCH $H_{3}$ at C-6". C.8", C.6'", C-8'"), 3.86 (lH. dd, $\left.J=10.4,4.0 \mathrm{~Hz} . \mathrm{H}_{\mathrm{b}}-6\right) .3 .85(\mathrm{lH}$, d. $\left.J=12.0 \mathrm{~Hz}, \mathrm{H}_{2}-6^{\prime}\right) .3 .80(1 \mathrm{H}$, dd. $J=9.2,8.8 \mathrm{~Hz}, \mathrm{H}-4)$. $3.78(\mathrm{lH} . \mathrm{m} . \mathrm{H}-5) .3 .74$ (lH. dd. $J=9.2 .8 .8 \mathrm{~Hz}$. H-2). 3.64 (lH. dd. $\left.J=12.0 .4 .0 \mathrm{~Hz} . \mathrm{H}_{\mathrm{l}}-6^{\prime}\right) .3 .35(\mathrm{lH}, \mathrm{t} . J=9.2 \mathrm{~Hz}$. H3') $3.26\left(2 \mathrm{H} . \mathrm{m}, \mathrm{H} \cdot 4^{\prime}\right.$. H-5'), 3.23 (lH, dd. $J=9.2,8.0 \mathrm{~Hz}$, H-2) ppm: ${ }^{13} \mathrm{C}$ NMR (2:1 CD 3 OD-DMSO- $\left.d_{6 .} .100 \mathrm{MHz}\right): \delta$ 168.3 (C. C-1"'), 167.0 (C. C.1"). 149.2 (C. C-6". C.6"'. C8". C-8'"), $148.5\left(\mathrm{CH}, \mathrm{C}-3^{\prime \prime}\right), 147.0\left(\mathrm{CH}, \mathrm{C}-3^{\prime \prime}\right), 139.8(\mathrm{C}, \mathrm{C}-$ $7^{7 \prime \prime)}, 139.4$ (C, C-7"), 126.5 (C. C.4"'), 126.1 (C. C.4"), 116.3 $\left(\mathrm{CH}, \mathrm{C}-2^{\prime \prime \prime}\right), 115.0\left(\mathrm{CH}, \mathrm{C}-2^{\prime \prime}\right), 107.2\left(\mathrm{CH} . \mathrm{C}-5^{\prime \prime \prime}, 9^{\prime \prime \prime}\right), 106.9$ $\left(\mathrm{CH}, \mathrm{C}-5^{\prime \prime}, 9^{\prime \prime}\right), 104.6(\mathrm{CH}, \mathrm{C}-1$ '). $95.7(\mathrm{CH} . \mathrm{C}-1) .78 .6(\mathrm{CH}$, C-3), $78.0\left(2 \mathrm{CH}, \mathrm{C}-3^{\prime}, \mathrm{C}-5\right.$ ) $77.6(\mathrm{CH} . \mathrm{C}-5), 75.1$ (CH. C2), $72.4(\mathrm{CH}, \mathrm{C}-2) .71 .6\left(\mathrm{CH} . \mathrm{C}-4^{\prime}\right), 69.3\left(\mathrm{CH}_{2}, \mathrm{C}-6\right), 69.2$ $(\mathrm{CH}, \mathrm{C}-4), 62.7\left(\mathrm{CH}_{2}, \mathrm{C}-6^{\prime}\right), 57.0\left(\mathrm{CH}_{3}\right.$ at $\mathrm{C}-6^{\prime \prime} . \mathrm{C}-66^{\prime \prime} . \mathrm{C}-8^{\prime \prime}$, C-8'") ppm; HRTOFMS: $m z 777.2197[\mathrm{M}+\mathrm{Na}]^{-}$(calcd. for $\left.\mathrm{C}_{34} \mathrm{H}_{42} \mathrm{O}_{10}+\mathrm{Na}, 777.2218\right)$ : TLC (80:19:1 $\mathrm{CH}_{2} \mathrm{Cl}_{2}=\mathrm{MeOH}-$ $\left.\mathrm{H}_{2} \mathrm{O}\right): R_{f} 0.51$.

Determination of Radical Scavenging Activity. Test compounds $(20 \mu \mathrm{L})$ at concentration of $1.5 \mu \mathrm{g} / \mathrm{mL}$ to 100 $\mu \mathrm{g} / \mathrm{mL}$ were mixed with ethanolic solution $(80 \mu \mathrm{L})$ of $2.2-$ diphenyl-1-picrylhydrazyl (DPPH, $59 \mu \mathrm{g} / \mathrm{mL}$ ) in 96 well plate. Changes in absorbance were measured at $517 \mathrm{~nm}$ (at $24^{\circ} \mathrm{C}$ after 5 min slaking) in a 96-well plate reader (Tecan, A-5082. Salzburg. Austria). Radical scavenging activity was expressed in terms of $\mathrm{IC}_{50}$ (concentration required for a $50 \%$ decrease in absorbance of a control solution of DPPH) in $\mathrm{mM}$. Vitamin C (L-ascorbic acid) was served as a reference compound.

Hydrolysis of Compound 5 and Identification of Monosaccharides. ${ }^{14}$ Compound 5 ( $2 \mathrm{mg}$ ) was dissolved in $\mathrm{MeOH}$ $(0.6 \mathrm{~mL})$ and treated with a solution of aqueous $\mathrm{KOH}(2 \mathrm{M}$. $0.2 \mathrm{~mL}$ ) at room temperature for $1 \mathrm{~h}$. The reaction mixture was neutralized with $2 \mathrm{M} \mathrm{HCl}$ and dried under vacuum. The residue was dissolved in $2 \mathrm{M} \mathrm{HCl}(1 \mathrm{~mL})$ and heated at 100 ${ }^{\circ} \mathrm{C}$ for $4 \mathrm{~h}$. After cooling and concentration the hydrolysate was passed through a short column of $\mathrm{C}_{18}(40-63 \mu \mathrm{m})$ by stepwise gradient elution of a mixture of $\mathrm{H}_{2} \mathrm{O}$ to $\mathrm{MeOH}$. The $\mathrm{H}_{2} \mathrm{O}$ eluate was analyzed on silica gel TLC (3:1:1 isopropanol-AcOH- $\mathrm{H}_{2} \mathrm{O}$ ) and compared with authentic D-glucose $\left(R_{f} 0.72\right)$ and other monosaccharides. Compound 5 and $\mathbf{6}$ provided only glucose after hydrolysis.

\section{Results and Discussion}

The powdered seeds were successively extracted with $80 \%$ aqueous $\mathrm{MeOH}, \mathrm{MeOH}$, and $\mathrm{CH}_{2} \mathrm{Cl}_{2}$. The combined extracts were suspended in a mixture of hexane-aqueous 
$\mathrm{MeOH}$. The aqueous $\mathrm{MeOH}$ layer separated was partitioned between butanol and $\mathrm{H}_{2} \mathrm{O}$. The butanol layer was fractionated on a $\mathrm{C}_{1}$ silica gel flash column. The fractions were further subjected to a series of chromatography (silica gel MPLC and $\mathrm{C}_{1 \S}$ HPLC) to afford compounds, $1,2.3,4.5,6$ and 7 , in the yield of $150,9.55 .462 .46 .900$, and $48 \mathrm{mg}$. respectively.

Compound 2 was obtained as pale yellowish oil. The mass spectrum (HRTOFMS) displayed a protonated molecular ion $[\mathrm{M}+\mathrm{H}]^{+}$at $m z 389.1448$ (calcd. for $\mathrm{M}+\mathrm{H}, 389.1447$ ). indicating a molecular formula of $\mathrm{C}_{17} \mathrm{H}_{2} 4 \mathrm{O}_{10}$. UV maxima in $\mathrm{MeOH}$ were observed at 326.238 and $203 \mathrm{~mm}$. The infrared (IR) spectrum showed the presence of hydroxyl group (3417 $\left.\mathrm{cm}^{-1}\right)$, ester $\left(1704 \mathrm{~cm}^{-1}\right)$. double bond $\left(1633 \mathrm{~cm}^{-1}\right)$, and aromatic ring $\left(1603.1516 \mathrm{~cm}^{-1}\right)$. The ${ }^{1} \mathrm{H}$ NMR spectrum (methanol- $d_{4}$ ) showed a sharp signal at $\delta 3.89$ for two methoxy protons. two sets of doublets at $\delta 7.66$ and $6.43(\mathrm{~J}=$ $16 \mathrm{~Hz})$ for trans-configured olefinic protons. and a sharp singlet at $\delta 6.9 \mathrm{l}$ for two aromatic protons. These data indicate the presence of a sinapoyl moiety. ${ }^{15.16}$ The remaining part of the ${ }^{1} \mathrm{H}$ NMR spectrim showed the presence of eight protons coupled with six carbon signals from HSQC experiment: two methylene protons at $\delta 4.26$ and $4.46\left(\delta_{c}\right.$ $67.6)$, four methine protons at $\delta 3.97\left(\delta_{4} 70.8\right), 3.68\left(\delta_{i}\right.$ $73.4), 3.91\left(\delta_{\mathrm{c}} 70.7\right)$. and $3.80\left(\delta_{\mathrm{c}} 75.2\right)$. two methylene protons at $\delta 3.61$ and $3.70\left(\delta_{6} 64.3\right)$, which is characteristic of a saccharide or polyhydroxy chain. The ${ }^{1} \mathrm{H}-{ }^{1} \mathrm{H}$ COSY spectrum showed that geninally coupled methylene protons at $\delta 4.26$ and 4.46 were coupled with the proton at $\delta 3.97$. which was in turn coupled with the proton at $\delta 3.68$. Similarly. the remaining methylene protons at $\delta 3.61$ and 3.70 were coupled with the proton at $\delta 3.80$ (ddd, $J=6.0$. 4.8. $4.0 \mathrm{~Hz}$ ) which showed correlation with the methine proton at $\delta 3.91(\mathrm{lH}$. dd, $J=4.8 .2 .4 \mathrm{~Hz})$. which was in turn coupled with the proton at $\delta 3.68$. From this spin coupling network and the coupling constant values, the poly oxygenated chain was suggested to be glucitol (sorbitol). The ${ }^{1} \mathrm{H}^{-}{ }^{1} \mathrm{H}$ COSY correlations of the polyhydroxy chain with their coupling constants are shown in the Figure 1.

The glucitol moiety was further confirmed by the HMBC spectrum. The terminal methylene carbon $(\delta$ 67.6) was correlated with two methine protons at $\delta 3.97$ and 3.68 . Correlations of the remaining methylene carbon $(\delta 64.3)$ with $\delta 3.80(\mathrm{H}-5)$ and $3.91(\mathrm{H}-4)$ were also confirmed by HMBC analysis (Figure 2). Finally, the connectivity between two partial structures. sinapoyl and glucitol moiety. were determined by the HMBC spectnum. The proton signal at $\delta 4.26$ of glucitol moiety showed a ${ }^{3} J$ correlation with the carbonyl carbon ( $\delta$ 169.2) of sinapoyl moiety. indicating the

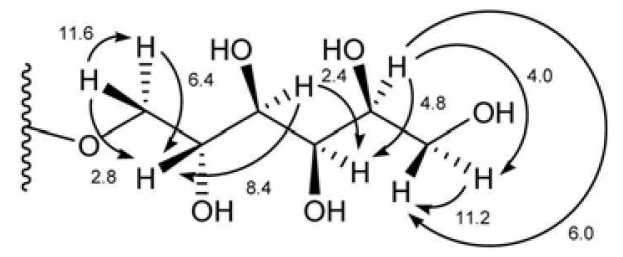

Figure 1. gCOSY with coupling constants of glucitol part of 2.

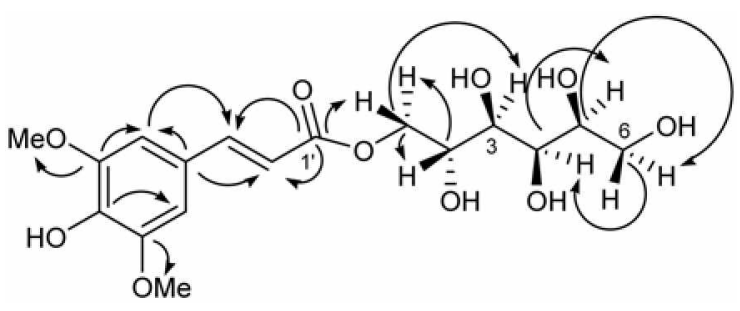

Figure $2 .{ }^{13} \mathrm{C}-{ }^{1} \mathrm{H}$ correlations in $\mathrm{gHMBC}$ of 2.

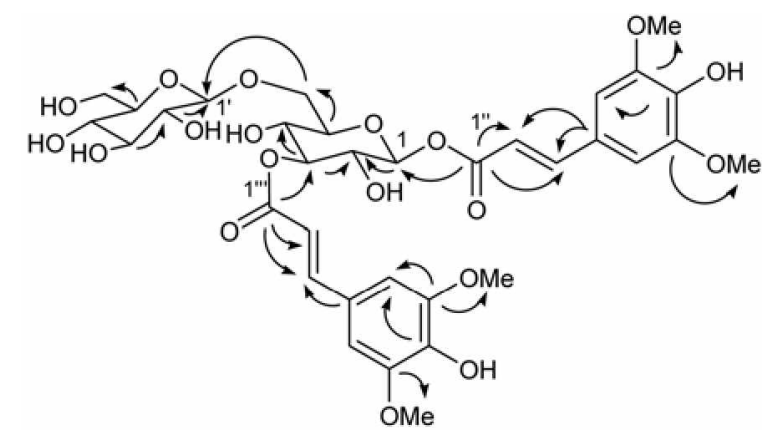

Figure $3 .{ }^{15} \mathrm{C}-{ }^{1} \mathrm{H}$ conelations in gHMBC of 5 .

glucitol unit was attached to the carbonyl carbon forming ester linkage. Although the optical rotation of compound 2 was measured to be $+5.13\left(c 0.13, \mathrm{CH}_{3} \mathrm{OH}\right)$, we were not able to determine the absolute stereochemistry of the glucitol moiety due to limited material availability. Thus. the structure of 2 was determined to be $1-0$-(sinapoyl)-glucitol.

Compound 5 was obtained as yellowish oil. $[\alpha]_{\mathrm{D}}^{3 \mathrm{il}}+1.41$ (c $0.92, \mathrm{CH}_{3} \mathrm{OH}$ ) and its molecular formula of $\mathrm{C}_{34} \mathrm{H}_{42} \mathrm{O}_{1}$ was derived from HRTOFMS (found $m z 777.2197$, calcd 777.2218 for $[\mathrm{M}+\mathrm{Na}]^{+}$). UV maxima in $\mathrm{MeOH}$ were observed at $328(4.51)$. $240(4.44)$ and $202(4.52) \mathrm{nm}$. The infrared (IR) spectrum of $\mathbf{5}$ showed the presence of hydroxyl group. ester, double bond. and aromatic ring. The ${ }^{1} \mathrm{H}$ NMR spectrum of 5 showed the signals for four aromatic protons at $\delta 6.92$ and 6.91 (two each, s). two sets of trans-olefinic protons at $\delta 7.71$ and 6.54 (both $J=16.0 \mathrm{~Hz}$ ); 7.66 and 6.44 (both $J=16.0 \mathrm{~Hz}$ ), and one singlet for four methoxy groups at $\delta 3.88$. These data indicate compound $\mathbf{5}$ contains two sinapoyl moieties. The remaining parts of ${ }^{1} \mathrm{H}$ NMR showed two anomeric protons ( $\delta 5.75$ and 4.36. each $\mathrm{lH}$, d. $J=8.8$, $8.0 \mathrm{~Hz}$, respectively). one proton at $\delta 5.22$, and overlapped eleven protons in the range of $\delta 3.23-4.21$. The ${ }^{13} \mathrm{C}$ NMR showed twelve oxygenated carbon signals. ${ }^{1} \mathrm{H}$ and ${ }^{13} \mathrm{C}$ NMR assignments from $\mathrm{HSQC}$ experiment indicated that these twelve oxygenated carbon signals are from two monosaccharide units. To identify the nature of the monosaccharides. compound 5 was hydrolyzed under acidic condition to yield only glucose by comparison of the $R_{f}$ value of the hydroly sate with authentic glucose. Thus. it was suggested that the compound $\mathbf{5}$ was an ester of trans-sinapic acid with two glucose units.

The ${ }^{1} \mathrm{H}-{ }^{-} \mathrm{H}$ COSY spectrum showed that the protons at $\delta$ 5.75 and $\delta 4.36$ were correlated with the protons at $\delta 3.74$ and $\delta 3.23$, respectively. For the rest of the ${ }^{1} \mathrm{H}$ NMR assignments. ID TOCSY experiments were conducted to assign 
signals of glucose units from overlapped proton signals. In ID TOCSY. one of the anomeric protons at $\delta 5.75(\mathrm{~d}, J=8.8$ $\mathrm{Hz}$ ) was correlated with protons at $\delta 5.22$ (dd. $J=9.2 .8 .8$ $\mathrm{Hz}), 4.21$ (brd, $J=10.4 \mathrm{~Hz}) .3 .86$ (dd, $J=10.4,4.0 \mathrm{~Hz}) .3 .74$ (dd. $J=9.2 .8 .8 \mathrm{~Hz}) .3 .80(\mathrm{dd}, J=9.2,8.8 \mathrm{~Hz}$ ), and $3.78(\mathrm{nt})$. Sintilarly, the other anomeric proton at $\delta 4.36$ (d. $J=8.0 \mathrm{~Hz}$ ) was correlated with the protons at $\delta 3.23-3.35$ (overlapped). $3.85(\mathrm{~d} . J=12.0 \mathrm{~Hz})$. and $3.64(\mathrm{dd}, J=12.0 .4 .0 \mathrm{~Hz})$.

In $\mathrm{HMBC}$ spectrum. the anomeric proton of one of the glucose moieties at $\delta_{\mathrm{H}} 5.75$ was correlated with the carbonyl carbon at $\delta .167 .0$ of one of the troms-sinapoyl moieties. indicating the attachment of sinapoyl group to anomeric position. The protons and carbons of the glucose were assigned from interpretation of HSQC and HMBC spectrum (HMBC correlation: $\mathrm{C}-\mathrm{I}$ to $\mathrm{H}-2$ : $\mathrm{C}-2$ to $\mathrm{H}-3 ; \mathrm{C}-3$ to $\mathrm{H}-2$ and $\mathrm{H}-4$ : C -4 to $\mathrm{H}-3$ and $\mathrm{H}-5$ : $\mathrm{C}-6$ to $\mathrm{H}-5$ ). Downfield shifts of the proton $\mathrm{H}-3(\delta 5.22)$ suggested the attachnient of the remaining sinapoyl moiety at this position. which was further confurned from the $\mathrm{HMBC}$ correlation of the carbon of the sinapoyl carbonyl group at $\delta 168.3$ with the $\mathrm{H}-3$ proton. Thus, both of the sinapoyl moieties were connected to the same glucose. The H-6 protons $(\delta 4.21$ and 3.86$)$ of the glucose were correlated with the remaining anomeric carbon at $\delta 104.6$ in the HMBC spectrum. Thus. one glucose was colunected at C-6 position of the other. Figure 3 showed the HMBC correlation of compound 5. The structure of compound 5 was determined to be $6-0-\beta$-D-glucopyranosyl$\beta \mathrm{D}$-(1-O-sinapoyl, 3-O-sinapoy l)glucopyranose or 1,3-disinapoylgentiobiose.

Compound 6 was obtained as yellowish oil and showed similar UV and IR with compound 5. Acidic hydrolysis of 6 provided only glucose as it was for $\mathbf{5}$. Mass spectra indicated compound 6 was an isomer of compound 5 . However. the $R_{f}$ value for 5 was 0.51 whereas for $6,0.38$ (TLC, silica gel. $80: 19: 1, \mathrm{CH}_{2} \mathrm{Cl}-\mathrm{MeOH}-\mathrm{H}_{2} \mathrm{O}$ ). Spectroscopic analysis and comparison with reported data showed the compound 6 was
6-O- $\beta$-D-glucopyranosyl- $\beta$-D-(1-O-sinapoyl. $2-0$-sinapoyl)glucopyranose ${ }^{2 \mathrm{i}}$ where sinapoyl groups were attached at $\mathrm{C} \cdot \mathrm{l}$ and $C \cdot 2$ position of the same glucose unit, contrary to compound 5 .

Sinapoyl esters. especially sinapoylated carbohydrates are widely distributed in plants. as antioxidant principles. most of them are ester of glucose, fructose, anhydroglucitol or gentiobiose. ${ }^{15.17}$ but there is no any report on glucitol ester. Thus. to the best of our knowledge compound 2. 1-O(sinapoyl)-D-glucitol, is a new natural product. Although many gentiobiose derivatives have been isolated from plants. ${ }^{18.19}$ almost all have acyl-substitutions at C.1, C-2, C$2^{\prime}$ or C-6' of gentiobiose such as sinapoyl. feruloyl or cimnamoyl moiety. 1,4-disinapoylgentiobiose has been reported $^{31}$ but there is no report on C.3 substitution. Thus, compound 5, 1,3-disinapoylgentiobiose. is a novel natural product.

In addition to the compound 2.5 . and 6 , four more sinapic acid derivatives were also isolated and were identified as sinapic acid (1) ${ }^{21} \beta$-D-fructofuranosy $1-\beta$-D-(6-O-sinapoyl)glucopyranoside (3). ${ }^{15}$ 1,2-disinapoyl- $\beta$-D-glucopyranose (4), ${ }^{18}$ and $6-0-\beta$-D-(2'-O-sinapoyl)-glucopyranosyl- $\beta$-D-(1O-suapoyl, 2-O-sinapoyl)glucopyranose $(7)^{19}$ (Figure 4 ) Their structures were characterized by comparison with

Table 1. Radical scavenging activity

\begin{tabular}{cc}
\hline Compound & IC 5 in $\mathrm{mM}$ \\
\hline $\mathbf{1}$ & 21.87 \\
$\mathbf{2}$ & 98.88 \\
$\mathbf{3}$ & 35.60 \\
$\mathbf{4}$ & 14.84 \\
$\mathbf{5}$ & 65.50 \\
$\mathbf{6}$ & 17.99 \\
$\mathbf{7}$ & 83.14 \\
L-Ascorbic acid & 11.53 \\
\hline
\end{tabular}

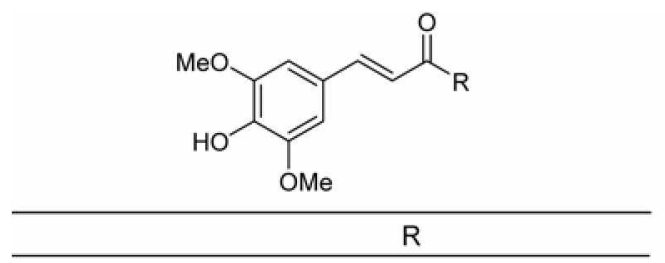

$\mathrm{OH}$<smiles>COC[C@H](O)[C@@H](O)[C@H](O)[C@H](O)CO</smiles>

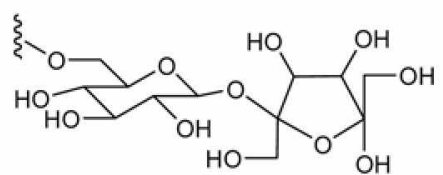

\begin{tabular}{|c|c|c|c|c|}
\hline & $\mathrm{R}_{1}$ & $\mathrm{R}_{2}$ & $\mathrm{R}_{3}$ & $\mathrm{R}_{4}$ \\
\hline 4 & Sinapoyl & Sinapoyl & $\mathrm{H}$ & $\mathrm{OH}$ \\
\hline 5 & Sinapoyl & $\mathrm{H}$ & Sinapoyl & \\
\hline 6 & Sinapoyl & Sinapoyl & $\mathrm{H}$ & \\
\hline 7 & Sinapoyl & Sinapoyl & $\mathrm{H}$ & \\
\hline
\end{tabular}

Figure 4. Structures of the isolates from Draba nemorosa 
known compounds from literatures. However, these are the first isolates from the plant Draba nemorosa.

The antioxidant potential of the isolated sinapoyl derivatives have been evaluated by their activity to scavenge a free radical. DPPH. according to Blois. ${ }^{20}$ The free radial scavenging activities of the isolates were found in the range of 14.84 to $98.88 \mathrm{mM}$. Compound 4 and 6 showed comparable activities to a reference compound, Vitamin $C$. with $\mathrm{IC}_{50} 14.84$ and $17.99 \mathrm{mM}$. respectively (Table 1). When sinapoyl moiety is substituted at $C-3$ position instead of at $C$. 2 position. the activity decreases approximately five times (5 is 6). The data obtained suggested that the major determinants for radical-scavenging capability are the presence of sinapoyl groups. nature of sugar units as well as the positions of substitutes on sugar moiety.

Acknowledgments. This work was supported by grants from the Korea Science and Engineering Foundation (Grant No. KOSEF R01-2003-000-10458-0) and in part by the Korean Research Foundation Grant funded by the Korean Govenmient (MOEHRD. 2004) for A. A. Ralinian.

\section{References}

1. Sum, Y. Free Radic. Biol. Mad 1990, 8. 583

2. Henning, B. Chow C. K. Free Ratic. Biol. Med 1988, f, 99

3. Buettner. R. G. Arch Biochem. Biophns. 1993. 300.535.

4. Dinis. T. C. P.: Maderia. V. M.: Almeida. L. M. Arch. Biochem.
Biophys 1994.315. 161

5. Ogata. M.: Hoshi. M.: Shimotohno. K.: Urano. S.: Endo. T. J. Ant. Oil Chent Soc. 1997. 74.557.

6. Hou. W. C: Lin, R. D.; Cheng, K. T.: Hung, Y. T: Cho, C. H: Chen. C. H. Hwang. S. Y.: Lee, M. H. Phvtomedicine 2003. 10. 170 .

7. Chang. S. T: Wu. J. H.: Wan1g. S. Y.: Kang. P. L.: Yang. N. S.: Shyur. L. F. J. Agric. Food Chem 2001. 19. 3420

8. Kahkonen. M. P.: Hopia. A. I.: Vuorela. H. T.: Raulha. J. P.: Pihlaja. K; Kujala. T. S.: Heinonen, M. J. Agric. Food Chem. 1999, 47. 3954.

9. Grundt, H. H.: Elven. R.: Brochmann. C. Flora 2005. 200, 321.

10. Kim. K. W.: Shin. J. H.: Moon. T.: Kim. M.: Lee. J.: Park. M. C.: Lee. I. Hol Cells. 2003. 16. 136.

11. Guil. J. L.: Rodriguez. G. I.: Torija. E. Plamt Foods Hum. Nitr. $1997.51,99$.

12. Kung. H. P.: Huang. W. Y. J. Am. Chem. Soc. 1949, 71, 1836

13. Regenbrecht, J; Strack, D. Phvtochemisty 1985, 24. 407

14. Hosova. T.: Yut1. Y. S.: Kunnugi. A. Tetrahe dron 2005, 61. 7037.

15. Ikeya. Y.: Sugama. K.: Okada. M.: Mitsuhashi. H. Chem. Pharn. Bull. 1991. 39.2600

16. Francisco, A.; Barberan, T.: Gil. M. I.; Ferreres. F; Lorente. F. T. Phytochemisny 1992, 31, 3097.

17. Dietz, H.: Winterhalter. P. Phytochemistry 1996, 42. 1005.

18. Takaya. Y: Kondo. Y.: Furukawa. T.: Niwa. M. J. Agric. Food Chem 2003. 51.8061.

19. Keith. R.: Casuscelli. F.: Colquhoun. I. J.: Rhodes. M. T. C. Ptntochemistry 1997, 45,1683

20. Hase. T.; Hasegawa, K. Plytochemistry 1982. 21, 1021.

21. Sakushima, A.: Coskunt. M.: Maoka, T. Phytochemistry 1995, 40. 483.

22. Blois. M. S. Nature 1958. 181. 1199 